\title{
Mitochondrial DNA variability in natural populations of Hawaiian Drosophila. I. Methods and levels of variability in $D$. silvestris and $D$. heteroneura populations
}

\author{
Rob DeSalle*, L. Val Giddingst, \\ and Alan R. Templeton
}

Department of Biology, Washington University, St. Louis, Missouri, U.S.A.

\begin{abstract}
We describe techniques by which mitochondrial DNA (mtDNA) restriction site information can be obtained for up to 16 different restriction endonucleases on individual Hawaiian Drosophila, in particular $D$. silvestris and $D$. heteroneura. We have constructed mtDNA restriction site maps for a total of forty-eight wild caught genomes of both species, from seven major collecting sites on the island of Hawaii. Levels of variability are, in general, high in $D$. silvestris ( $p$ of Ewens et al., 1981 =0.0486) and lower in $D$. heteroneura $(p=0 \cdot 0327)$. Measures of population subdivision using Nei's $G_{s t}$ indicate that about 50-60 per cent of the observed variability is due to interdemic subdivision. In accordance, populations within a species show a much lower level of variability, however some populations harbour individuals that are very divergent from the rest of their conspecifics at the same locality. We review two possible mechanisms that could explain the presence of these divergent individuals, hybridisation and the effects of stochastic branching processes.
\end{abstract}

\section{INTRODUCTION}

Analysis of mitochondrial DNA (mtDNA) using restriction endonuclease digestion is useful in the study of evolution in matriarchal lineages (Brown and Wright, 1977; Lansman et al., 1981; Avise et al., 1979; Ferris et al., 1983). The rapid evolution of mtDNA (Brown et al., 1979; Brown, 1980; Avise et al., 1979) means that mtDNA restriction site analysis is also valuable in studying closely related taxa. The Hawaiian Drosophilia are a well characterised group of closely related organisms in which matriarchal population structure has greatly affected evolution as founder events by one or a few gravid females are probably involved in their extensive genetic differentiation (Carson et al., 1970; Carson and Kaneshiro, 1976; Carson, 1978, 1983; Carson and Templeton, 1984; but also see Barton and Charlesworth, 1984).

The closely related species pair, D. silvestris and $D$. heteroneura have undergone extensive morphological and behavioural differentiation as a result of founder events on the island of Hawaii

Present Addresses: *Department of Genetics, Washington University Medical School, St. Louis, Missouri 63110, † Office of Technology Assessment, United States Congress, Washington, D.C.
(Carson, 1983; Kaneshiro, 1983). However, chromosome studies and isozyme analysis show little genetic change within and between these species. $D$. silvestris and $D$. heteroneura are homosequential in their polytene chromosome banding patterns. No diagnostic, fixed inversions exist between the two species nor among populations within each of them (Carson, 1983). Isozyme studies (Craddock and Johnson, 1979; Sene and Carson, 1977) suggest a moderate degree of population heterozygosity, but also show a high degree of genetic similarity not only within populations but between $D$. silvestris and $D$. heteroneura, with no fixed diagnostic alleles between these two generally sympatric species. Hunt and Carson (1982) have used the relatedness of single copy DNA sequences by DNA reassociation techniques to show that small, but significant differences $(0.6$ per cent sequence divergence) do exist between these two species.

Here we utilise restriction endonuclease cleavage analysis of mtDNA to study genetic differentiation in $D$. silvestris and $D$. heteroneura. We describe techniques that allow detection of restriction site polymorphisms in mtDNA isolated from a single individual Hawaiian Drosophila for up to 16 restriction enzymes. In addition, we deter- 
mine the level of variability and the degree of genetic differentiation among mtDNA sequences in natural populations of the two species and analyse the patterns of mtDNA variability within populations in light of what is known about population structure (Craddock and Johnson, 1979; Carson, 1983) and natural hybridisation (Kaneshiro and Val, 1977) in these species.

\section{MATERIALS AND METHODS}

\section{(i) Flies and fly stocks}

Flies were captured by standard Hawaiian Drosophilia collecting techniques (Carson, 1983) on the western side of Hawaii at Waihaka and Hualalai (fig. 1), and on the eastern side of Hawaii at Olaa and Piihonau (fig. 1). Males were frozen at $-80^{\circ} \mathrm{C}$ while females were allowed to establish isofemale lines before being frozen. Thirty-two isofemale lines were analysed.

Two males and nine females that did not produce isofemale lines from the west side were analysed, as were four males from the east side (table 1).

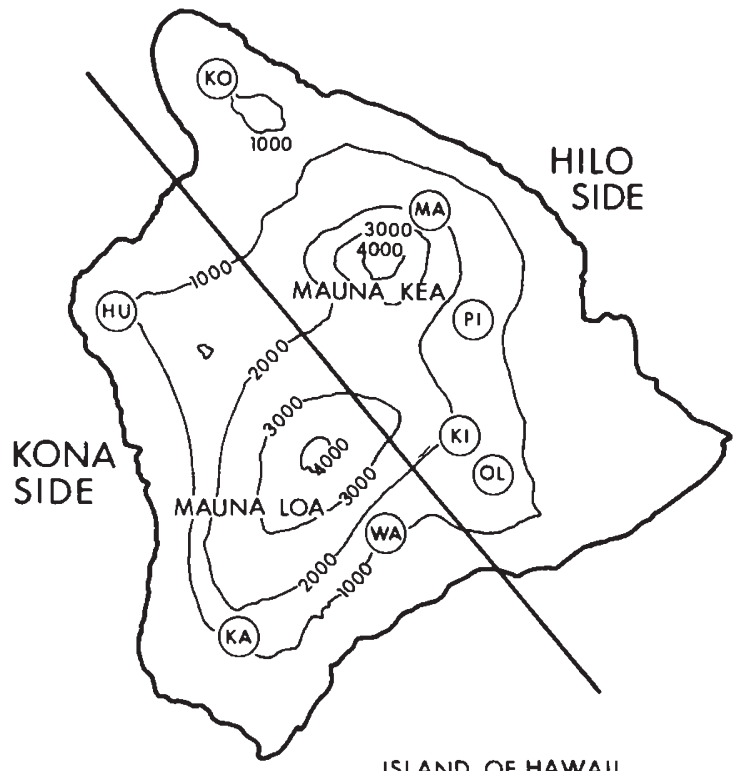

Figure 1 Location of the collecting sites of $D$. silvestris and $D$. heteroneura on the island of Hawaii for this study. The solid line running across the map represents the artificial demarcation of the east side from the west side. Contour lines represent elevation in metres. Abbreviations are $\mathrm{HU}=$ Hualalai, $\mathrm{KA}=\mathrm{Kahuku}, \mathrm{WA}=\mathrm{Waihaka}, \mathrm{PI}=$ Piihonua, $\mathrm{KI}=$ Kilauea and $\mathrm{OL}=$ Olaa. See table 1 for sample sizes analysed for each population.
Table 1A Isofemale lines used in this study

\begin{tabular}{|c|c|c|}
\hline Isoline & Species & Trapping locality \\
\hline LVGP1 & $\mathrm{S}$ & Piihonua-PI \\
\hline LVGP10 & $\mathrm{S}$ & Piihonua-PI \\
\hline LVGP12 & $\mathrm{S}$ & Piihonua-PI \\
\hline LVGP13 & $\mathbf{S}$ & Piihonua-PI \\
\hline WPMO1 & $\mathbf{S}$ & Olaa-OL \\
\hline WPMO4 & $\mathrm{S}$ & Olaa-OL \\
\hline WPMO6 & $\mathrm{S}$ & Olaa-OL \\
\hline U28T2 & $\mathrm{S}$ & Kilauea-KI \\
\hline W12B7 & $\mathrm{S}$ & Maulua-MA \\
\hline W33B45 & $\mathbf{S}$ & Kohala-KO \\
\hline W48B1 & $\mathrm{S}$ & Hualalai-KU \\
\hline W48B2 & $\mathbf{S}$ & Hualalai-HU \\
\hline W48G4 & $\mathrm{S}$ & Hualalai-HU \\
\hline W48G5 & $\mathrm{S}$ & Hualalai-HU \\
\hline W48G10 & $\mathrm{S}$ & Hualalai-HU \\
\hline U26B9 & $\mathrm{S}$ & Kahuku-KA \\
\hline W33B2 & $\mathbf{H}$ & Waihaka-WA \\
\hline W33B3 & $\mathbf{H}$ & Waikaka-WA \\
\hline W33B4 & $\mathbf{H}$ & Waihaka-WA \\
\hline W33B5 & $\mathbf{H}$ & Waihaka-WA \\
\hline W33B7 & H & Waihaka-WA \\
\hline W33B8 & $\mathbf{H}$ & Waihaka-WA \\
\hline W33B13 & $\mathbf{H}$ & Waihaka-WA \\
\hline W33B14 & $\mathbf{H}$ & Waihaka-WA \\
\hline W33B16 & $\mathbf{H}$ & Waihaka-WA \\
\hline W33G6 & $\mathbf{H}$ & Waihaka-WA \\
\hline W33G7 & $\mathbf{H}$ & Waihaka-WA \\
\hline W33G10 & $\mathbf{H}$ & Waihaka-WA \\
\hline W33G11 & $\mathbf{H}$ & Waihaka-WA \\
\hline W48G3 & $\mathbf{H}$ & Hualalai-HU \\
\hline W48B6 & $\mathbf{H}$ & Hualalai-HU \\
\hline Q71G12 & $\mathbf{H}$ & Olaa-OL \\
\hline
\end{tabular}

$\mathrm{S}=D$. silvestris.

$\mathrm{H}=D$. heteroneura .

\section{(ii) DNA isolation}

D. melanogaster mtDNA used in making probe and in cloning experiments was isolated from embryos by the method of Bultmann and Laird (1973). Nuclear DNA, mitochondrial DNA and RNA were isolated from single Hawaiian Drosophila by the method of Coen et al. (1981). Plasmid DNA was isolated by methods of Maniatis et al. (1982).

(iii) Cloning of a specific Hind III D. melanogaster mtDNA fragment

Purified mtDNA and puc8 DNA (Vierra and Messing, 1983) were cleaved to completion with Hind III and ligated. The resultant ligated DNA was transformed into $E$. coli JM83 by the method of Maniatis et al. (1982). The recombinant plasmid pDm-mt-258 which corresponds to the Hind-C fragment in Bonner et al. (1977) was isolated by 
Table 1B Single flies analyzed in this study

\begin{tabular}{lll}
\hline Designation & Species/sex & Locality \\
\hline LVGP2 & S/F & Piihonua-PI \\
LVGP8 & S/F & Piihonua-PI \\
LBGP10 & S/F(ISO) & Piihonua-PI \\
LVGP12 & S/F(ISO) & Piihonua-PI \\
LVGP11 & S/F & Piihonua-PI \\
LVGP15 & S/F & Piihonua-PI \\
LVGP16 & S/F & Piihonua-PI \\
LVGP17 & S/F & Piihonua-PI \\
WPMO1 & S/F & Olaa-OL \\
WPMO2 & S/F(ISO) & Olaa-OL \\
WPMO3 & S/F & Olaa-OL \\
WPMO4 & S/F(ISO) & Olaa-OL \\
WPMO5 & S/F & Olaa-OL \\
WPMO6 & S/F(ISO) & Olaa-OL \\
WPMOM1 & S/M & Olaa-OL \\
WPMOM2 & S/M & Olaa-OL \\
W48BA & S/M & Hualalai-HU \\
W48AA & S/M & Hualalai-HU \\
W48BC & S/M & Hualalai-HU \\
W48BD & S/M & Hualalai-HU \\
\hline
\end{tabular}

$\mathrm{S}=D$. silvestris.

$\mathrm{H}=D$. heteroneura.

$\mathrm{F}=$ Female.

$\mathrm{F}(\mathrm{ISO})=$ Mother of the designated isoline.

$\mathrm{M}=$ Male.

filter colony hybridisation (Maniatis et al., 1982) using purified $D$. melanogaster mtDNA as probe.

\section{(iv) Restriction, electrophoresis, and \\ Southern transfer}

Up to 18 different restriction reactions could be performed on DNA from a single fly. Restriction enzymes were purchased from New England Biolabs and used as described by the distributor. Digested DNA was separated on $0.6-1.2$ per cent argarose gels and the gels stained with ethidium bromide and photographed under short wave UV light. Restriction fragments were denatured in the gel in $0.5 \mathrm{M} \mathrm{NaOH}$ and $1.5 \mathrm{M} \mathrm{NaCl}$ for 1 hour and neutralised in $0.5 \mathrm{M}$ Tris and $3 \mathrm{M} \mathrm{NaCl}$ for at least 2 hours. Transfer of DNA from the gel to nitrocellulose was done by the Southern blotting technique described in Maniatis et al. (1982). Nitrocellulose filters were baked at $65^{\circ} \mathrm{C}$ for at least 2 hours to affix the DNA to the nitrocellulose before hybridisation.

\section{(v) Nick translation, hybridisation and autoradiography}

Purified D. melanogaster mtDNA or plasmid DNA was nick translated by the method of Rigby et al. (1976) to a specific activity of $5\left(10^{7}\right) \mathrm{cpm} / \mu \mathrm{g}$. Approximately $2\left(10^{5}\right) \mathrm{cpm}$ of nick translated probe was hybridised to each filter under the following conditions; $5 \mathrm{X} \mathrm{SSC}, 0.25 \mathrm{M} \mathrm{KPB}, 2$ per cent SDS and $1 \mathrm{X}$ Denhardt's at $65^{\circ} \mathrm{C}$ for at least 12 hours. Filters were washed in 2 changes of $2 X$ SSC, 1 per cent SDS, and $1 \mathrm{X}$ Denhardt's at $37^{\circ} \mathrm{C}$ for 1 hour. Autoradiography was as described in Maniatis et al. (1982) for exposure times of 1-10 days.

\section{(vi) Melting point determinations}

Melting point determinations were carried out by a modification of the methods in Appels and Dvorak (1982). Three replicates of total cellular DNA $(2 \mu \mathrm{g})$ from the appropriate species were denatured in $0.15 \mathrm{ml}$ of $0.2 \mathrm{~N} \mathrm{NaOH}$ by boiling for 2-5 minutes. The samples were then cooled on ice. Ammonium acetate $(0.03 \mathrm{ml}$ of $5 \mathrm{M}$ solution) was then added to the DNA and the solution was dotted onto nitrocellulose. The DNA was baked onto the filter at $80^{\circ} \mathrm{C}$ for $1-2$ hours. Hybridisation of saturating amounts of $D$. melanogaster mtDNA was performed as described above. Determination of the melting point was accomplished by serial transfer of the filters to $0.5 \mathrm{ml}$ aliquots of $2 \mathrm{X} \mathrm{SSC}$ at the desired temperature for 5-10 minutes at which time the aliquots were placed on ice and the filters transferred to the next vial. To determine the amount of released labelled probe, $5 \mathrm{ml}$ of scintillation cocktail was added and 5 minute counts of each vial were obtained. The activity released was then computed as a cumulative per cent loss of radioactivity.

\section{(vii) Sizing of fragments and restriction mapping}

Lambda phage fragments of known size were run on each gel as size standards. Fragments on autoradiographs were sized either by using a computer program designed after the algorithm of Schaffer and Sederoff (1981) or by plotting the lambda standard data on semilog graph paper. The mtDNA restriction maps were generated by single and double digestions of the mtDNA. The restriction enzyme Nru I was particularly useful in the mapping studies. A single invariant site occurs in all of the individuals we examined. This Nru I site is located in the second two codons of the COII gene (DeBruijn, 1983) and was used in all of our double digestion experiments. Orientation of the mtDNA circle was accomplished by using $\mathrm{pDm}$ mt-258 (Hind-C fragment mtDNA) and analogy to known conserved sites in D. melanogaster and D. virilis (Shah and Langley, 1979) and D. yakuba (Clary et al., 1982). 


\section{RESULTS}

To develop a rapid and efficient system for visualising restriction endonuclease digested mtDNA patterns we used heterologous probes rather than direct visualisation by EtBr staining (Powell, 1983; Powell and Zuniga, 1983). Because Hawaiian picture-winged Drosophila are difficult to culture in large numbers, use of tissue to isolate purified mtDNA for probe was not feasible. $D$. melanogaster has mtDNA which hybridises to picture wing mtDNA and is easy to culture in large numbers. In addition, all or part of the mtDNA genome of this species has been cloned so that large scale plasmid or phage isolation of probe is possible (Bonner et al., 1977; di Bruijn, 1983; Clary et al., 1982). We tested the similarity of $D$. melanogaster mtDNA to Hawaiian Drosophila mtDNA by making melting point determinations (Appels and Dvorak, 1982) for heterologous and homologous combinations of mtDNA under normal hybridisation conditions (fig. 2). A sigmoidal release of radioactivity with rising temperature indicates that the sequences used behaved as DNA duplexes. Both $D$. silvestris and $D$. heteroneura yielded a delta $T_{m} 50$ of about $14^{\circ} \mathrm{C}$ or approximately 15 per cent nucleotide sequence divergence from $D$. melanogaster. The similarity between the picture-winged mtDNA and $D$. melanogaster mtDNA is hence great enough to allow detection of fragments as small as $500 \mathrm{bp}$ (fig. 4).

Enough mtDNA could be isolated from a single fly for several different restriction endonuclease

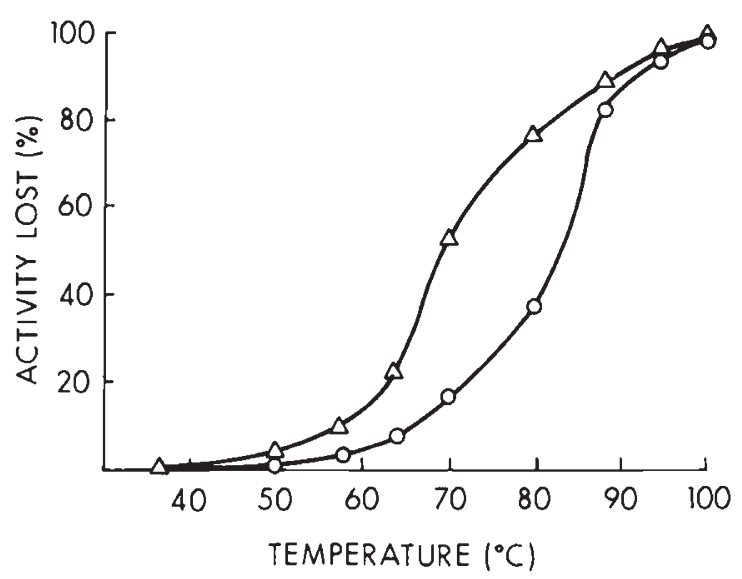

Figure 2 Melting curves for homologous and heterologous combinations of mtDNA. $(\triangle) D$. melanogaster- $D$. melanogster; $(\bigcirc)$ Picture Wing-D. melanogaster. The Picture Wing-D. melanogaster data points were obtained by combining the data for both $D$. silvestris and $D$. heteroneura because the data for these two species was homogeneous. digests. Fig. 3 shows the result of digesting nucleic acids isolated by the method of Coen et al. (1982) with Xho I, an enzyme which cuts once in the mtDNA circle of $D$. silvestris and D. heteroneura. Only one sixth of the DNA isolated from a single fly was run per lane to produce this gel and autoradiograph, and even further dilution of our DNA samples from single individuals produced visible bands of hybridisation. We split the DNA isolated from a single fly into enough aliquots to produce interpretable data for 16 different endonucleases per individual for the flies listed in table 1. Fig. 4 shows an autoradiograph using one eighteenth of the single fly DNA per lane. This approach makes it possible to study populations taken directly from nature without the need for rearing many flies in the lab.

Data for the 34 isofemale lines (table 1) were collected for 23 restriction enzymes, while data on wild caught adults that did not produce isofemale lines (table 1) were collected for 16 endonucleases that were known to cleave the mtDNA circle at least once. Here we report the results of our analysis using these 16 endonucleases.

All restriction sites were mapped by using combinations of single and double digests. They were oriented with $D$. melanogaster mtDNA coding regions by using pDm-mt-258, a cloned probe specific for a region containing the COI, COII, COIII, URF-5 and ATPase 6 genes (Clary et al., 1983). Fig. 5 and table 2 show the restriction endonuclease maps for the mtDNA of $D$. silvestris and $D$. heteroneura. The 16 restriction endonucleases analysed gave 73 mapped restriction sites, of which only 28 were present in all the individuals examined $(n=48)$. An average of 44 sites per individual were mapped, with 16 sites per individual being polymorphic. There were 36 distinct mtDNA genomes or haplotypes among the 48 individuals examined.

Levels of variability within a population and a species may be estimated using one of several methods (Brown et al., 1979; Nei and Li, 1979; Ewens et al., 1981; Engels, 1982; Hudson, 1982). The common statistic for the measurement of variability is $p$, the percentage of sites which are polymorphic in the sample. In order to assess the genetic structure in natural populations of $D$. silvestris and $D$. heteroneura we calculated $p$ values for the D. silvestris populations at Olaa $(n=8)$, Piihonua $(n=10)$ and Hualalai $(n=9)$, and the $D$. heteroneura populations at Waihaka $(n=13)$ and Hualalai $(n=2)$. Measures of $p$ were also obtained for all $D$. silvestris pooled $(n=32)$, all $D$. heteroneura pooled $(n=18), D$. heteroneura 


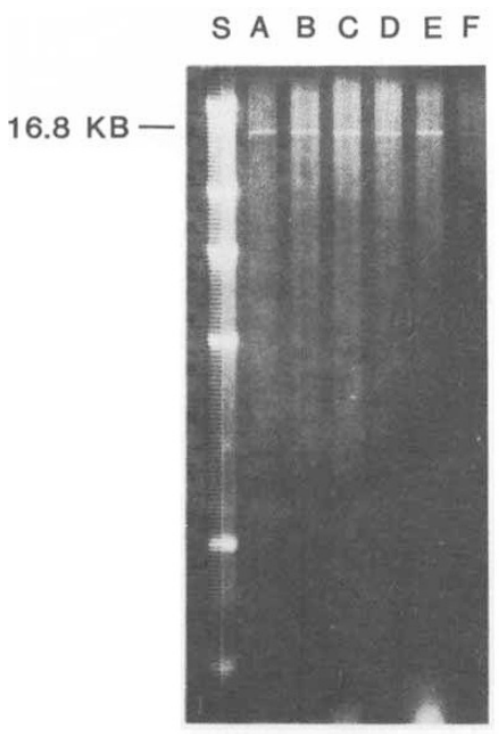

A

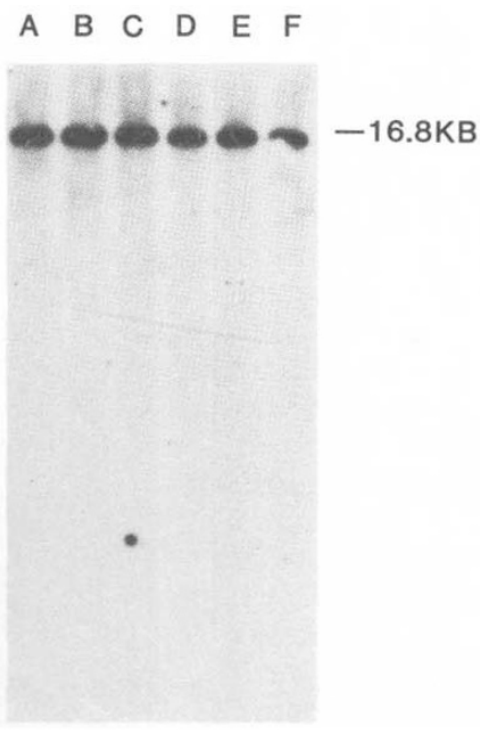

B

Figure 3 Panel A shows DNA prepared by the method of Coen et al. (1981), cut with Xho I and electrophoresed on a $0 \cdot 6$ per cent agarose gel. The gel was then stained with ethidium bromide and photographed under short wave UV light. mtDNA can be recovered in relatively large quantities in this type of extraction. Panel B shows an autoradiograph of a Southern blot prepared from the gel in panel A which had been hybridised to nick translated $D$. melanogaster mtDNA. One sixth of the DNA from a single fly was used per lane to produce this gel and autoradiograph. $A=U 26 B 9, B=U 28 T 2, C=W 12 B 7, D=L V G P 1, E=W P M O 1$, $\mathrm{F}=\mathrm{O} 71 \mathrm{G} 12, \mathrm{~S}=\lambda$ Hind III standard.

from the west side of Hawaii $(n=17), D$. silvestris from the west side $(n=10)$ and $D$. silvestris from the east side $(n=22)$ (table 3$)$.

Takahata and Palumbi (1985) have developed techniques for the estimation of within deme $(I)$ and between deme $(J)$ identity probabilities from restriction maps of mtDNA. These techniques also allow an estimation of relative interdeme gene flow. Table 4 lists the identity probabilities, $I$ and $J$ for pairwise comparisons of the four demes in this study with relatively large sample size. $G_{s t}$ values can then be estimated from the within $(I)$ and between $(J)$ identity probabilities in pairwise comparisons. According to Takahata and Palumbi (1985) $G_{s t}$ estimates the fraction of genetic variation within a population that is due to interdeme differences. Large $G_{s t}$ values for a pairwise comparison suggests a relatively low rate of interdeme gene flow, while small values of $G_{s t}$ suggest a high degree of genetic exchange between the demes. The $G_{s t}$ value for the four large populations considered together ( D. silvestris from Olaa, Piihonua and Hualalai and $D$. heteroneura from Waihaka) is 0.66 , while the $G_{s t}$ value for the three $D$. silvestris populations with large sample size is 0.52 .

The estimator, $p$ (Ewens et al., 1981) can also be used as a measure of genetic distance among individuals. Some individuals within these populations were moderately differentiated from the rest of the members of their population. Two divergent $D$. silvestris (WPMO1 from Olaa and W48B2 from Hualalai) are of particular interest. Table 5 shows the genetic distance measures for $D$. silvestris populations at Olaa and Hualalai. W48B2 from Hualalai is two to three times more distant from its conspecifics at Hualalai than is the average $D$. silvestris from this locality. Cluster analysis using the genetic distance measure and UPGMA techniques (Sneath and Sokal, 1973) revealed that W48B2 actually clustered with $D$. heteroneura rather than with $D$. silvestris from Hualalai (Fig. 6(a)). The same is true for $D$. silvestris line U26B9 from Kahuku. Because of the recent divergence of these two species (more recent than the age of the island of Hawaii which is about 500,000 years [McDougall and Swanson, 1972]) convergence of restriction sitè state is unlikely to explain the high genetic similarity among these individuals (see Templeton, 1983a). Hybridisation between the two species (Ferris et al., 1983; Powell, 1983) and the effects of stochastic branching processes on maternal lineage survivorship (Avise et al., 1983; Avise et al., 1984) as discussed in the next section are two possible explanations for this observation. 


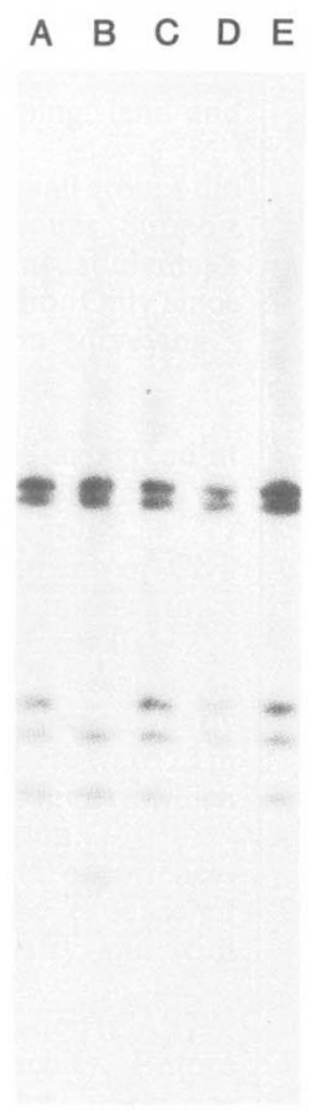

Figure 4 Autoradiograph of Hind III cut DNA from several $D$. silvestris individuals. The autoradiograph was produced by hybridising highly purified nick translated $D$. melanogaster mtDNA to a Southern blot of Hind III cut D. silvestris DNA. One eighteenth of the total DNA from a single fly was used per lane to produce this autoradiograph. This autoradiograph also demonstrates the ability of this technique to detect very small restriction fragments. $\mathrm{A}=\mathrm{WPM}-\mathrm{M} 1, \mathrm{~B}=\mathrm{WPM}-\mathrm{M} 2, \mathrm{C}=\mathrm{LVGP} 2, \mathrm{D}=\mathrm{LVGP} 8$ and $\mathrm{E}=$ LVGP11.
In contrast to these divergent lines, WPMO1 from Olaa has a genetic distance to its conspecifics that is $2-3$ times greater than that observed among its conspecifics from the same locality. Genetic distance between this line and $D$. heteroneura $(\mathrm{Q} 71 \mathrm{G12})$ at Olaa however, is even greater. Cluster analysis reveals no clustering of $D$. heteroneura with $D$. silvestris in the population at Olaa (fig. 6(b)).

\section{DISCUSSION}

mtDNA restriction endonuclease data has recently been applied to the population genetics of humans and apes (Brown, 1980; Cann et al., 1982; Ferris et al., 1981), lizards (Brown and Wright, 1979), rodents (Lansman et al., 1981; Brown and Simpson, 1981; Ferris et al., 1983; Avise et al., 1983) and Drosophila (Shah and Langley, 1979; Powell, 1983; Powell and Zuniga, 1983). Vertebrate mtDNA is relatively easy to analyse as it is available in relatively large amounts per individual (Giles et al., 1980; Lansman et al., 1981; Ferris et al., 1983). As Powell (1983) points out, however, mtDNA restriction techniques in Drosophila systems usually demands that isofemale lines are used to obtain enough tissue to isolate mtDNA. We have established isofemale lines, but have also developed an alternative approach for analysis of Hawaiian Drosophila mtDNA, which takes advantage of the large size of the Hawaiian Drosophila (10 to 15 times as large as D. melanogaster) and extensive similarity between $D$. melanogaster mtDNA and Hawaiian Drosophila mtDNA, we can examine restriction patterns of mtDNA from a single fly for a large number of restriction endonucleases.

\section{CONSERVED}
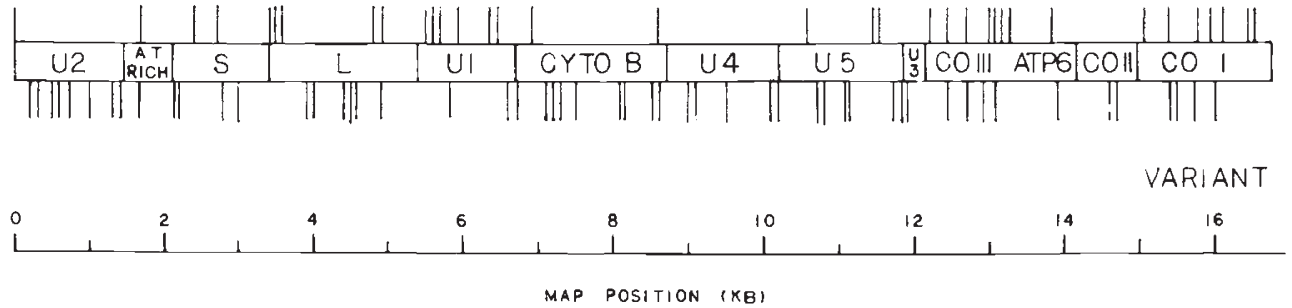

Figure 5 Restriction site map of $D$. silvestris and $D$. heteroneura mtDNA showing the distribution of conserved and variant sites. The relative map positions for all 23 enzymes that we have used are listed jn table 2 . The sites generated by BStE II, Bst XI, Nco I, Nru I, Sac II, and Xba I were not included in the analysis of the levels of variation in natural populations. Pst I did not cleave the mtDNA circle of $D$. silvestris and $D$. heteroneura. Gene designations are as follows: U2=Unidentified reading frame $2, \mathrm{AT} \mathrm{RICH}=\mathrm{AT}$ base region, $\mathrm{S}=\mathrm{mt}$ small ribosomal $\mathrm{RNA}$ gene, $\mathrm{L}=\mathrm{mt}$ large ribosomal $\mathrm{RNA}$ gene, $\mathrm{U} 1=\mathrm{Unidentified}$ reading frame 1, CYTO B=cytochrome b, U4= Unidentified reading frame 4, U5= Unidentified reading frame 5 , U3 = Unidentified reading frame 3 , CO III = cytochrome oxidase subunit III, ATP6 = ATPase 6 gene, CO II = cytochrome oxidase subunit II and CO I = cytochrome oxidase subunit $I$. 
Table 2 List of restriction sites and their relative map position from the conserved NruI site in the CO I gene

\begin{tabular}{llll}
\hline Enzyme & Site & Map position & $\begin{array}{l}\text { Conserved/ } \\
\text { polymorphic }\end{array}$ \\
\hline Ava II & $a 1$ & 3.0 & $p$ \\
& $a 2$ & 4.5 & $f b l$ \\
& $a 3$ & 4.9 & $f b l$ \\
& $a 4$ & 6.9 & $c$ \\
& $a 5$ & 8.6 & $c$ \\
& $a 6$ & 9.2 & $p$ \\
& $a 7$ & 11.7 & $p$ \\
& $a 8$ & 12.7 & $p$ \\
& $a 10$ & 14.7 & $p$
\end{tabular}

$\begin{array}{llr}\text { BamH I } & b l & 7 \cdot 1 \\ B c l \text { I } & d 1 & 0 \cdot 3 \\ & d 2 & 1 \cdot 4 \\ & d 3 & 1 \cdot 7 \\ & d 4 & 3 \cdot 5 \\ & d 5 & 11 \cdot 4 \\ & d 6 & 12 \cdot 7 \\ & d 7 & 15 \cdot 7\end{array}$

Bst N I $\quad g 1 \quad 0.2$

g2 0.5

g3 1.7

g4 $5 \cdot 7$

g $5 \quad 12 \cdot 4$

g6 $13 \cdot 1$

g7 13.9

g10 $\quad 15.9$

$\begin{array}{llrl}\text { Cla I } & c 1 & 3.5 & c \\ & c 2 & 4.8 & c \\ \text { EcoR I } & e 1 & 0.7 & p \\ & e 2 & 4.9 & c \\ & e 3 & 5.9 & c \\ & e 4 & 11.5 & c\end{array}$

EcoR V $\quad j$

$j 1 \quad 4.4$

$j 2 \quad 7 \cdot 3$

j3 $\quad 11.1$

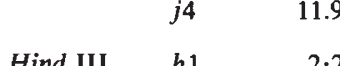

h1 $\quad 2 \cdot 2$

h3 $\quad 3 \cdot 5$

h4 $5 \cdot 6$

h5 $\quad 6.6$

h7 $\quad 10.8$

h8 $\quad 11.2$

h9 11.9

h10 $\quad 13 \cdot 2$

h12 $\quad 15 \cdot 9$

$\begin{array}{lll}\text { Hpa I } & m 1 & 2 \cdot 4\end{array}$

$m 2 \quad 5 \cdot 8$

$m 3 \quad 7 \cdot 5$

$m 4 \quad 8 \cdot 1$

$m 5 \quad 10 \cdot 2$

$m 6 \quad 12 \cdot 9$

$\begin{array}{lll}K p n I & k 1 & 8 \cdot 5\end{array}$

$k 2 \quad 16 \cdot 0$

$k 3 \quad 16 \cdot 6$

Table 2 (cont.)

\begin{tabular}{llll}
\hline Enzyme & Site & Map position & $\begin{array}{l}\text { Conserved/ } \\
\text { polymorphic }\end{array}$ \\
\hline Pvu II & $p 1$ & $7 \cdot 2$ & $p$ \\
& $p 2$ & $8 \cdot 1$ & $p$ \\
& $p 3$ & $10 \cdot 7$ & $c$ \\
& $p 4$ & $13 \cdot 0$ & $c$ \\
& $p 5$ & $15 \cdot 1$ & $c$ \\
& $p 6$ & 16.1 & $c$ \\
Sst I & $s 1$ & 4.5 & $p$ \\
& $s 2$ & $6 \cdot 7$ & $f b l$ \\
& $s 3$ & 10.6 & $c$ \\
Sma I & $t 1$ & 8.6 & $f b l$ \\
Stu I & $u 1$ & 0.5 & $p$ \\
& $u 2$ & 5.5 & $c$ \\
& $u 3$ & $15 \cdot 5$ & $f l$ \\
Xho I & $x 1$ & 13.2 & $c$ \\
Xmn I & $w 1$ & $0 \cdot 0$ & $p$ \\
& $w 2$ & 12.2 & $c$ \\
& $w 3$ & 13.8 &
\end{tabular}

Restriction sites that were mapped but not analysed for variability in this study:

$\begin{array}{llrl}\text { BstE II } & f 1 & 1 \cdot 3 & p \\ & f 2 & 10 \cdot 1 & f b l \\ \text { Nco I } & o 1 & 1 \cdot 0 & p \\ & o 2 & 4 \cdot 0 & p \\ & o 4 & 9 \cdot 5 & f l \\ & o 5 & 16 \cdot 5 & c \\ \text { Nru I } & n 1 & 0 \cdot 0 & c \\ \text { Sac II } & r 1 & 2 \cdot 2 & f b l \\ & r 2 & 6 \cdot 4 & c \\ \text { Xba I } & v 1 & 2.7 & c \\ & v 2 & 3 \cdot 9 & p \\ & v 3 & 6 \cdot 3 & c \\ & v 4 & 13 \cdot 2 & c\end{array}$

Pst I no sites

$p=$ polymorphic; $c=$ conserved; $f b l$-polymorphic, but fixed between localities.

We find that, unlike the situation for isozyme and karyotype comparisons, considerable variability in mtDNA exists in most natural populations of these species. In general, the restriction site variants observed in the east side $D$. silvestris populations are more numerous than on the west, occur in only one or a few individuals and are rarely fixed between populations. In the $D$. heteroneura populations and the west side $D$. silvestris populations, the restriction site variants are less numerous, occur in several individuals in a population and are fixed more frequently between populations. 
Table 3 The percentage of sites which are polymorphic in the sample $(p)$, the sample size $(n)$ and the variance associated with the estimation of $p[\operatorname{var}(p)]$ for several populations with relatively large sample sizes

\begin{tabular}{llrl}
$\begin{array}{l}\text { Species } \\
\text { Side of Island } \\
\text { Trapping site }\end{array}$ & $p$ & $n$ & $\operatorname{var}(p)$ \\
\hline D. silvestris & $0.0486^{*}$ & 32 & 0.00110 \\
West side & $0.0306 \dagger$ & 10 & 0.00049 \\
$\quad$ Hualalai & 0.0242 & 9 & 0.00014 \\
East side & 0.0427 & 22 & 0.00067 \\
Piihonua & 0.0198 & 10 & 0.00035 \\
Olaa & 0.0246 & 8 & 0.00043 \\
D. heteroneura & 0.0327 & 17 & 0.00053 \\
West & 0.0319 & 16 & 0.00056 \\
Hualalai & 0.0169 & 2 & 0.00032 \\
Waihaka & 0.0102 & 13 & 0.00028 \\
\hline
\end{tabular}

* Significantly different at $p<0.001$ from the pooled $D$. heteroneura value.

$\dagger$ Significantly different at $p<0.01$ from the $D$. silvestris east side pooled value.

Table $4 I, J$ and $G_{s t}$ values for four populations of $D$. silvestris and $D$. heteroneura with large sample sizes

\begin{tabular}{lllll}
\hline & Olaa $(S)$ & Piih $(S)$ & Hual $(S)$ & Waih $(H)$ \\
\hline Olaa & $\underline{0.823}$ & 0.782 & 0.681 & 0.629 \\
Piihonua (Piih) & 0.25 & $\underline{0.851}$ & 0.669 & 0.633 \\
Hualalai (Hual) & 0.58 & 0.63 & $\underline{0.906}$ & 0.704 \\
Waihaka (Waih) & 0.75 & 0.78 & $\underline{0.81}$ & $\underline{0.98}$ \\
\hline
\end{tabular}

Within deme identity or $I$ values for the designated populations are given on the diagonal and are underlined. Between deme identity probabilities or $J$ values are given in the upper part of the matrix. $G_{s t}$ values of the pairwise comparisons are given in the lower part of the matrix. $I, J$ and $G_{s t}$ were estimated by the procedures outlined in Takahata and Palumbi (1985). Abbreviations: $S=D$. silvestris and $H=D$. heteroneura.

There is a general similarity between the trends in mtDNA variability and those observed in chromosomal variability of $D$. silvestris and $D$. heteroneura. Table 3 shows that $D$. heteroneura mtDNA is about 30 per cent less variable than $D$. silvestris ( $p$ values for $D$. heteroneura and $D$. silvestris are 0.0327 and 0.0486 respectively, which are significantly different at $p<0.001$ using the Student's $t$ test). The same trend exists for chromosomal data. While $D$. heteroneura has only one polymorphic inversion, $D$. silvestris has 11 (Carson, 1983) and Craddock and Johnson (1979) show that $D$. heteroneura has a maximum of 0.538 heterozygous inversions per individual, while $D$. silvestris has between 0.714 and 2.259 heterozygous inversions per individual.

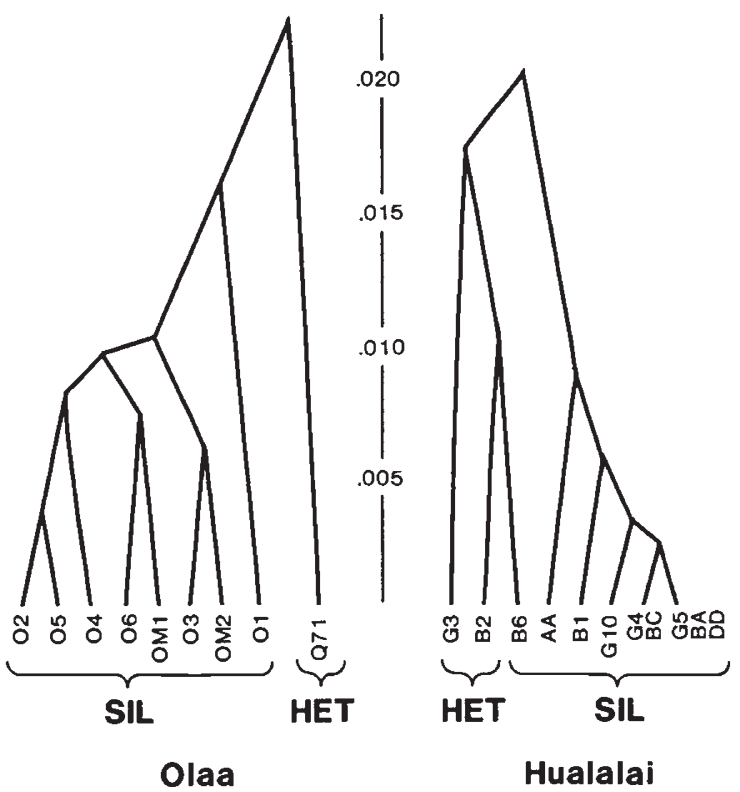

Figure 6 UPGMA generated phenograms of the Olaa and the Hualalai populations of $D$. silvestris. Abbreviations for Olaa: $01=$ WPMO1, O2 $=$ WPMO2, O3 =WPMO3, O4 = WPMO4, O5=WPMO5, O6=WPMO6, OM1 = WPM-M1, OM2 = WPM-2 and Q71 = Q71G12. Abbreviations for Hualalai: $\mathrm{G} 3=\mathrm{W} 48 \mathrm{G} 3, \mathrm{~B} 6=\mathrm{W} 48 \mathrm{~B} 6, \mathrm{~B} 2=$ $\mathrm{W} 48 \mathrm{~B} 2, \mathrm{~B} 1=\mathrm{W} 48 \mathrm{~B} 1, \mathrm{G} 4=\mathrm{W} 48 \mathrm{G} 4, \mathrm{G} 5=\mathrm{W} 48 \mathrm{G} 5, \mathrm{G} 10=$ $\mathrm{W} 48 \mathrm{G} 10, \mathrm{BA}=\mathrm{W} 48 \mathrm{BA}, \mathrm{AA}=\mathrm{W} 48 \mathrm{AA}, \mathrm{BC}=\mathrm{W} 48 \mathrm{BC}$ and $\mathrm{BD}=\mathrm{W} 48 \mathrm{BD}$.

Furthermore, within $D$. silvestris, the east side populations seem to be more variable than the west side populations for both mtDNA restriction sites and chromosomal inversions. The west side populations have only five polymorphic inversions, while the east side populations have between seven and 11 inversions (Carson, 1983). Similarly, as table 3 shows, the $p$ values for the west side and east side were 0.0306 and 0.0427 respectively, which were significantly different at $p<0.01$ using the Student's $t$ test. However, isozyme data, show no difference in the levels of variability between the two species (Johnson et al., 1975; Craddock and Johnson, 1979; Sene and Carson, 1977).

The $G_{s t}$ values (table 4 ) for the comparisons of the four relatively large samples in this study allow an estimate of the levels of gene flow. The relatively large $G_{s t}$ value for all the populations considered together $\left(G_{s t}=0.66\right)$ indicates that about twothirds of the observed variation in mtDNA can be attributed to interdeme variation. Similarly, the relatively large $G_{s t}$ value $\left(G_{s t}=0.55\right)$ indicates a large amount of subdivision within $D$. silvestris. This pattern of population subdivision is also observed in all the pairwise $G_{s t}$ comparisons, 
Table 5A $P$ estimates for comparisons within the Olaa $D$. silvestris populations. All individuals are listed in tables 1 and 2 and are listed in this table without the WPM prefix. A single $D$. heteroneura from the same locality, Q71G12 (abbreviated as Q71 in this table) is also listed

\begin{tabular}{|c|c|c|c|c|c|c|c|c|c|}
\hline & O1 & $\mathrm{O} 2$ & $\mathrm{O} 3$ & $\mathrm{O} 4$ & O5 & O6 & OM1 & $\mathrm{OM} 2$ & O71 \\
\hline $\mathrm{O} 1$ & - & 0.019 & 0.013 & 0.015 & 0.019 & 0.017 & 0.017 & 0.019 & 0.026 \\
\hline $\mathrm{O} 2$ & & - & 0.013 & 0.008 & 0.004 & 0.006 & 0.010 & 0.012 & 0.026 \\
\hline $\mathrm{O} 3$ & & & - & 0.013 & 0.013 & 0.011 & 0.008 & 0.006 & 0.018 \\
\hline 04 & & & & - & 0.008 & 0.009 & 0.010 & 0.008 & 0.026 \\
\hline O5 & & & & & - & 0.009 & 0.010 & 0.008 & 0.026 \\
\hline O6 & & & & & & - & 0.008 & 0.013 & 0.024 \\
\hline OM1 & & & & & & & - & 0.010 & 0.021 \\
\hline OM2 & & & & & & & & - & 0.020 \\
\hline Q71 & & & & & & & & & - \\
\hline
\end{tabular}

Table 5B $P$ estimates for comparisons within the $D$. silvestris Hualalai population. All individuals are listed in tables 1 and 2 and are listed in this table without the W48 prefix. Two $D$. heteroneura from the same locality are also listed in this table (W48G3 abbreviated as G3 and W48B6 abbreviated as B6)

\begin{tabular}{|c|c|c|c|c|c|c|c|c|c|c|c|}
\hline & B1 & B2 & G4 & G5 & G10 & BA & $\mathrm{AA}$ & $\mathrm{BC}$ & BD & G3 & B6 \\
\hline B1 & - & 0.020 & 0.007 & 0.005 & 0.007 & 0.005 & 0.010 & 0.007 & 0.005 & 0.025 & 0.029 \\
\hline B2 & & - & 0.017 & 0.016 & 0.014 & 0.016 & 0.011 & 0.017 & 0.016 & 0.019 & 0.011 \\
\hline G4 & & & - & 0.002 & 0.003 & 0.002 & 0.007 & 0.000 & 0.002 & 0.019 & 0.024 \\
\hline G5 & & & & - & 0.002 & 0.000 & 0.005 & 0.002 & 0.000 & 0.020 & 0.025 \\
\hline G10 & & & & & - & 0.002 & 0.007 & 0.004 & 0.002 & 0.019 & 0.023 \\
\hline BA & & & & & & - & 0.005 & 0.002 & 0.000 & 0.020 & 0.025 \\
\hline $\mathrm{AA}$ & & & & & & & - & 0.007 & 0.005 & 0.022 & 0.021 \\
\hline $\mathrm{BC}$ & & & & & & & & - & 0.002 & 0.019 & 0.024 \\
\hline $\mathrm{BD}$ & & & & & & & & & - & 0.020 & 0.025 \\
\hline G3 & & & & & & & & & & - & 0.017 \\
\hline B6 & & & & & & & & & & & - \\
\hline
\end{tabular}

except for the Olaa and Piihonua $D$. silvestris comparison. The low $G_{s t}$ value for this comparison may reflect a high degree of interdeme contact between these populations. Whether this results from migration or is caused by recent divergence of these two populations cannot be determined by this analysis. The $G_{s t}$ values given in table 5 also indicate that the degree of isolation of the east side $D$. silvestris (Olaa and Piihonua) from the west side $D$. silvestris (Hualalai) is nearly the same as the degree of isolation from $D$. heteroneura (Waihaka). This suggests that there is extensive differentiation of the east and west side $D$. silvestris.

In contrast to the chromosomal and isozyme data (where there are no fixed variants between populations and between species) there are several restriction site variants which are fixed between the two species and even among populations within a species. The fixed differences within $D$. silvestris are found only between the east side populations and the west side populations.

The presence of genetically distinct individuals within the $D$. silvestris populations (table 5 and fig. 6) suggests a relatively complex population structure for this species. First, $D$. silvestris individuals are capable of hybridising in nature with D. heteroneura. Kaneshiro and Val (1977) have presented morphological data on natural hybridisation and mtDNA provides genetic data supporting the possibility of hybridisation. Chromosomal (Craddock, 1974) and isozyme data (Sene and Carson, 1977; Craddock and Johnson, 1979 ) on the west side $D$. silvestris and $D$. heteroneura populations, however indicate that the two species at single localities are relatively dissimilar, and the isozyme data supports the contention that hybridisation is limited at least in the populations studied by Craddock and Johnson (1979).

If hybridisation has occurred between $D$. silvestris and $D$. heteroneura, its impact on the genetic structure of the species involved is not the same as in other animals where hybridisation has been inferred from mtDNA analysis (Ferris et al., 1983; Powell, 1982) and in which there are distinct differences between the nuclear genomes of the 
species involved. In these cases mtDNA gene pools of hybridizing species become homogenized, with loss of one of the mtDNA lineages. In the $D$. silvestris and $D$. heteroneura system little differentiation has occurred in the nuclear genome (Johnson et al., 1975; Sene and Carson, 1978; Craddock and Johnson, 1979; Carson, 1983; Hunt and Carson, 1982), but the mtDNA pools of $D$. silvestris and $D$. heteroneura have not been homogenised.

The genetic similarity observed between some west side $D$. silvestris and $D$. heteroneura individuals may alternatively be related to the stochastic branching processes involved in matriarchal lineage survivorship (Avise et al., 1983; Avise et al., 1984). If the mtDNA lineages giving rise to W48B2 (D. silvestris from Hualalai) and U26B9 (D. silvestris from Kahuku) came from the $D$. silvestris / D. heteroneura split, then these divergent $D$. silvestris lineages would appear more closely related to $D$. heteroneura than to the other $D$. silvestris lineages. Avise et al. (1984) have shown that for very young populations or species some of the mtDNA lineages within the population or species will have originated before separation from the ancestral lineage. Since the populations and species in this study are certainly young, this is a plausible explanation.

The presence of divergent individuals in the $D$. silvestris populations that are not suspected of being hybrids with $D$. heteroneura might result from such processes; but might also result from migration, strong local population subdivision or both. More detailed collecting and mtDNA restriction site analysis are needed to resolve this question.

The present data on mtDNA restriction sites show a high degree of variability within and between populations. Many restriction sites are fixed between populations and between the two species, allowing a genetic analysis of their relationships to be made. Such an analysis using distance methods (Ewens et al., 1981) and nonparametric phylogeny testing methods (Templeton, $1983 a, b)$ appears in the accompanying paper.

Acknowledgements We thank William P. Mull, Rick N. Williams and K. Y. Kaneshiro for assistance in collecting the flies used in this study; and Linden Teromoto and K. Y. Kaneshiro for help in rearing the flies in the lab. We also thank $K$. Y. Kaneshiro, H. L. Carson, T. Crease, J. Learn, E. A. Zimmer, S. M. Williams and R. Zink for comments on earlier drafts: We would also like to thank an anonymous reviewer for extensive comments and criticism. This work was supported by $\mathrm{NIH}$ Grant RO1 GM31571 to Alan Templeton.

\section{REFERENCES}

APPELS, R. AND DVORAK, J. 1982. The wheat ribosomal DNA spacer region: Its structure and variation in populations among species. Theor. Appl. Genet., 63, 337-348.

AVISE, J. C., LANSMAN, R. A. AND SHADE, R. O. 1979. The use of restriction endonucleases to measure mitochondrial DNA sequence relatedness in natural populations. I. Population structure and evolution in the genus Peromyscus. Genetics, 92, 279-295.

AVISE, J. C., SHAPIRA, J. F., DANIEL, S. W., AQUADRo, C. F. AND LANSMAN, R. A. 1983. Mitochondrial DNA differentiation during the speciation process in Peromyscus. Mol. Biol. Evol., 1, 38-56.

AVISE, J. C., NEIGEL, J. E. AND ARNOLD, J. 1984. Demographic influences on mitochondrial DNA lineage survivorship in animal populations. J. Mol. Evo., 20, 99-105.

BARTON, N. H. AND CHARLESWORTH, B. 1984. Genetic revolutions, founder effects and speciation. Ann. Rev. Ecol. Syst., $15,133-164$.

BONNER, J. J,, BERNIGER, M. AND PARDUE, M. L. 1977. Transcription of polytene chromosomes and of the mitochondrial genome in Drosophila melanogaster. Cold Spring Harbor Symposium on Quantitative Biology, 42, 803-814.

BROWN, G. AND SIMPSON, M. 1981. Intra- and interspecific variation of the mitochondrial genome in Rattus norvegicus and Rattus rattus: Restriction enzyme analysis of variant mitochondrial DNA molecules and their evolutionary relationships. Genetics, 97, 125-143.

BROWN, W. M. 1980. Polymorphism in mitochondrial DNA of humans as revealed by restriction endonuclease analysis. Proc. Natl. Acad. Sci. USA, 77, 3605-3609.

BRoWN, W. M. AND WRIGHT, J. W. 1977. Mitochondrial DNA analysis and the origin and relative age of parthenogenetic lizards. Science, 203, 1247-1249.

BROWN, W. M., GEORGE, M. AND WILSON, A. C. 1979. Rapid evolution of animal mitochondrial DNA. Proc. Natl. Acad. Sci. USA, 76, 1967-1971.

BULTMANN, H. AND LAIRD, C. D. 1973. Mitochondrial DNA from Drosophila melanogaster. Bioch. et Biophys. Acta, 299, 196-209.

CANN, R, L., BROWN, W. M. AND WILSON, A. C. 1982. Evolution of human mitochondrial DNA: A preliminary report. In Human Genetics, Part A: The Unfolding Genome, Alan R. Liss, Inc., pp. 157-165.

CARSON, H. L. 1978. Speciation and sexual selection in the Hawaiian Drosophila. In Brussard, P. F. (ed.) Ecological Genetics: The Interface, Springer-Verlag, New York, pp. 93-107.

CARSON, H. L. 1983. Evolution of Drosophila on the newer Hawaiian volcanoes. Heredity, 48, 3-25.

CARSON, H. L. AND KANESHIRO, K. Y. 1976. Drosophila of Hawaii: Systematics and ecological genetics. Ann. Rev. Ecol. Systematics, 7, 311-346.

CARSON, H. L. AND TEMPLETON, A. R. 1984. Genetic revolutions in relation to speciation phenomena: The foundling of new populations. Ann. Rev. Ecol. Syst., 15, 97-131.

CARSON, H. L., HARDY, D. E., SPIETH, H. T. AND STONE, W. S. 1970. The evolutionary biology of the Hawaiian Drosophilidae. In Hecht, M. K. and Steere, W. C. (eds.) Essays in Evolution and Genetics in Honor of Theodosius Dobzhansky. Appleton-Century-Crofts, New York, pp. 437-543.

CLARY, D. O., GODDARD, J. M., MARTIN, S. C., FAURON, C. M. R. AND WOLSTENHOLME, D. R. 1982. Drosophila mitrochondrial DNA: A novel gene order. Nucl. Acids. Res., 10, 6619-6637. 
COEN, E. S., THODAY, J. N. AND DOVER, G. 1982. Rate of turnover of structural variants in the rDNA gene family of Drosophila melanogaster. Nature, 295, 564-568.

CRADDOCK, E. M. 1974. Reproductive relationships between homosequential species of Hawaiian Drosophila. Evolution, 28, 593-606.

CRADDOCK, E. M. AND JOHNSON, W. E. 1979. Genetic variation in Hawaiian Drosophila. V. Chromosomal and allozymic diversity in Drosophila silvestris and its homosequential species. Evolution, 33, 137-155.

DE BRUIJN, H. M. L. 1983. Drosophila melanogaster mitochondrial DNA, a novel gene organization and genetic code. Nature, 304, 234-241.

ENGELS, W. J. 1981. Estimating genetic divergence and genetic variability with restriction endonucleases. Proc. Natl. Acad. Sci. USA, 78, 6329-6333.

EWENS, W. J., SPIELMAN, R. S. AND HARRIS, H. 1981. Estimation of genetic variation at the DNA level from restriction endonuclease data. Proc. Natl. Acad. Sci. USA, 78, 37483750 .

FERRIS, S., WILSON, A. C. AND BROWN, W. M. 1981. Extensive polymorphism in the mitochondrial DNA of apes. Proc. Natl. Acad. Sci. USA, 78, 6319-6323.

FERRIS, S., SAGE, R. D., HUANG, C., NIELSEN, J. T., RITTE, U. AND WILSON, A. C. 1983. Flow of mitochondrial DNA across a species boundary. Proc. Natl. Acad. Sci. USA, 80, 2097-2416.

Giles, R. E., BLANC, H., CANN, H. M. AND WALlACE, D. C. 1980. Maternal inheritance of human mitochondrial DNA. Proc. Natl. Acad. Sci. USA, 77, 6715-6719.

HUDSON, R. R. 1982. Estimating genetic variability with restriction endonucleases. Genetics, 100, 711-719.

HUNT, J. A. AND CARSON, H. L. 1982. Evolutionary relationships of four species of Hawaiian Drosophila as measured by DNA reassociation. Genetics, 104, 353-364.

JOHNSON, W. E., CARSON, H. L., KANESHIRO, K. Y., STEINER, W. M. M. AND COOPER, M. M. 1975. Genetic variation in Hawaiian Drosophila. II. Allozymic differentiation in the D. planitibia subgroup. From Markert, C. L. (ed.) Isozymens IV: Genetics and Evolution, Academic Press, New York, pp. 563-583.

KANESHIRO, K. Y. 1983. Sexual selection and direction of evolution in the biosystematics of Hawaiian Drosophilidae. Ann. Rev. Entomol, 28, 161-178.

KANESHIRO, K. Y. AND VAL, F. C. 1977. Natural hybridization between a sympatric pair of Hawaiian Drosophila. Amer. Nat., 111, 897-902.

LANSMAN, R. A., SHADE, R. O., SHAPIRA, J. F. AND AVISE, J. C. 1981. The use of restriction endonucleases to measure mitochondrial sequence relatedness in natural populations. III. Techniques and potential applications. J. Mol. Evol., 17, 214-226.

MANIATIS, T., FRITSCH, E. F. AND SAMBROOK, J. 1982. Molecular Cloning: A Laboratory Manual. Cold Spring Harbor Laboratory Press.

MCDOUGALL, I. AND SWANSON, D. A. 1972. Potassium argan ages of lavas from the Hawi and Pololu volcanic series, Kohala Volcano, Hawaii, Geol. Soc. Am. Bull., 83, 37313738.

NEI, M. AND LI, W. H. 1979. Mathematical model for studying variation in terms of restriction endonucleases. Proc. Natl. Acad. Sci. USA, 76, 5269-5273.

POWELL, J. R. 1983. Intraspecific cytoplasmic gene flow in the absence of nuclear gene flow; evidence from Drosophila. Proc. Natl. Acad. Sci. USA, 80, 492-494.

POWELL, J. R. AND ZUNIGA, M. C. 1983. A simplified procedure for studying mtDNA polymorphisms. Biochem. Genet., 21, 1051-1055.

RIGBY, P. W., DIECKMAN, M., RHODES, C. AND BERG, P. 1977. Labelling deoxiribonucleic acid to high specific activity in vitro by nick translation with DNA polymerase I. J. Mol. Biol., 113, 237-248.

SENE, F. M. AND CARSON, H. L. 1977. Genetic variation in Hawaiian Drosophila. IV. Close allozymic similarity between $D$. silvestris and $D$. heteroneura from the island of Hawaii. Genetics, 86, 187-198.

SHAH, D. M. AND LANGLEY, C. 1979. Inter- and intraspecific variation in restriction site maps of Drosophila mitochondrial DNAs. Nature, 281, 696-699.

SCHAFFER, H. E. AND SEDEROFF, R. R. 1981. Improved estimation of DNA fragment lengths from agarose gels. Analytical Biochemistry, 115, 113-122.

SNEATH, P. AND SOKAL, R. 1973. Numerical Taxonomy. W. H. Freeman and Company, San Francisco.

TAKAHATA, N. AND PALUMBI, S. R. 1985. Extranuclear differentiation and gene flow in the finite island model. Genetics, 109, 441-457.

TEMPLETON, A. R. $1983 a$. Convergent evolution and nonparametric inferences from restriction fragment and DNA sequence data. In Weir, B., Statistical Analysis of DNA Sequence Data, Marcel Dekker, New York, pp. 151-179.

TEMPLETON, A. R. 1983 b. Phylogenetic inference from restriction endonuclease cleavage site maps with particular refer. ence to the evolution of humans and apes. Evolution, 37, 221-244.

VIERRA, J. AND MESSING, J. 1983. The pUC plasmids, m $13 \mathrm{mp} 7$ derived system for insertion mutagenesis and sequencing with synthetic universal primers. Gene, 19, 259-268. 